\title{
ПОРІВНЯЛЬНА ЕФЕКТИВНІСТЬ СИСТЕМИ ЛАМІНАРНОГО ПНЕВМОЗАХИСТУ ДЛЯ ПРОТИДІЇ ПРОНИКНЕННЮ БАКТЕРІЙНИХ АГЕНТІВ
}

\author{
๑І. М. Кліщ, А. О. Ковальчук, І. І. Медвідь, А. В. Павлишин, С. І. Климнюк
}

Тернопільський національний медичний університет імені І. Я. Горбачевського МОз України

PEЗЮМЕ. Пандемія коронавірусу COVID-19 зумовила потребу в розробці нових засобів індивідуального захисту органів дихання, які 6 поєднували у собі надійність та ергономічність використання. У дослідженні проводилась експериментальна оцінка бактеріальної непроникності інноваційної концепт-моделі пневмошолома з ламінарною системою подачі повітря.

Мета - провести порівняльну оцінку фільтрувальної здатності запропонованої концепт-моделі пневмошолома з визначенням її проникності для бактерійної культури мікрококів. Оцінити особливості потенційного бактерійного обсіменіння у внутрішньому просторі пристрою.

Матеріал і методи. Проведено тестування розробленої концепт-моделі пневмошолома для визначення їі стійкості проти бактерійних агентів (Micrococcus luteus) при шестигодинній безперервній експлуатації. Мікроорганізми подавалися у вигляді аерозолю на зовнішній фільтр діючого пристрою з подальшим титруванням і посівом. Оцінку бактерійного обсіменіння проводили шляхом підрахунку колонієутворювальних одиниць. Для вивчення особливостей потенційного бактерійного обсіменіння у внутрішньому просторі пристрою використовувалась шефілдська голова-манекен. Дослідження повторювали при заміні фільтрів марлевими масками та при їх вилученні. У якості контролю було розміщено ємність із живильним середовищем усередину вимкненого пневмошолома на зазначений термін.

Результати. Використання пневмошолома у повній комплектації протидіяло просоченню бактерійного аерозолю, що проявлялось у відсутності росту на поживних середовищах. При відсутності фільтруючих складових найбільші рівні бактерійного обсіменіння визначались на внутрішній поверхні скла та верхній частині обличчя шефілдської голови-манекена. При заміні фільтрів на марлеві маски вдалось затримати 98,8 \% мікроорганізмів у порівнянні з результатами застосування пневмошолома без захисних бар'єрів.

Висновки. Підтвердження ефективності фільтраційної та ізолювальної здатності пропонованої системи стосовно її непроникності для тестової культури із відсутністю росту на живильних середовищах впродовж шести годин безперервної роботи. Підтверджена захищеність нижнього контуру пневмошолома від мікроорганізмів.

КЛючОВІ слОВА: система ламінарного пневмозахисту; пневмошолом; протибактеріальний захист; мікрококи.

Вступ. Пандемія коронавірусу COVID-19 стала серйозним викликом для сучасної медицини. Серед засобів запобігання інфікуванню найдоступнішими у використанні є маски, респіратори, захисні окуляри, щитки $[2,4,5]$. Але, на жаль, застосування вищевказаних засобів не забезпечує повний захист від інфікування, адже кожен п'ятий інфікований коронавірусом в Україні $є$ медичним працівником [6]. Наведене обумовлює потребу в розробці нових методів індивідуального захисту органів дихання, які 6 одночасно вдовольняли критерії надійності, доступності та ергономічності $[1,4]$.

Мета - провести порівняльну оцінку фільтрувальної здатності запропонованої концепт-моделі пневмошолома з визначенням її проникності для бактерійної культури мікрококів. Оцінити особливості потенційного бактерійного обсіменіння у внутрішньому просторі пристрою.

Завдання. Оцінити надійність протибактеріального захисту фільтрів концепт-моделі у повній комплектації. Для порівняння ефективності повторити дослід із заміною фільтрів на марлеві маски або повним вилученням фільтруючих компонен- тів. Вивчити особливості потенційного бактеріального обсіменіння внутрішнього простору пневмошолома.

Матеріал і методи. Для дослідження ефективності бактеріальної фільтрації пропонованої респіраторної системи захисту була використана культура Micrococcus luteus. Цей мікроорганізм був обраний за свою неспроможність викликати захворювання у людей (за винятком осіб із вираженим імунодефіцитом), що робить його безпечним засобом для перевірки протибактеріального захисту [7]. Бактерійна суспензія із концентрацією $10^{6}$ КУО/мл подається на зовнішній фільтр пневмошолома за допомогою генератора аерозолю. Вихідний отвір спрямований на розміщену всередині пристрою чашку Петрі з рідким живильним середовищем. Після завершення досліду відбувається титрування та посів. Оцінка проводиться шляхом підрахунку колонієутворювальних одиниць (КУО) 3 множенням наведеного показника на ступінь розведення.

Для вивчення особливостей потенційного бактерійного обсіменіння у внутрішньому просторі пристрою використовується шефілдська голо- 
Огляди літератури, оригінальні дослідження, погляд на проблему, випадок з практики, короткі повідомлення ва-манекен. Після завершення досліду проводяться змиви з верхньої, нижньої частин обличчя, покритої пневмошоломом ділянки шиї, внутрішньої поверхні захисного скла. Дослідження повторюється при заміні фільтрів марлевими масками та при їх вилученні. Тривалість безперервної експлуатації запропонованої концепт-моделі - 6 год. Дослід був повторений шестикратно із кожним варіантом комплектації пристрою. У якості контролю було розміщено ємність із живильним середовищем усередину вимкненого пневмошолома на зазначений термін.

Результати й обговорення. Використання пневмошолома у повній комплектації протидіяло просоченню бактерійного аерозолю, що проявлялось у відсутності росту на середовищах (табл. 1). Для порівняння ефективності фільтри концепт-моделі були замінені на марлеві маски. Останні використовувались згідно з існуючими рекомендаціями - заміна маски проводилась кожні 4 год експлуатації. При цьому вдалось затримати 98,8 \% мікроорганізмів, $(0,08 \pm 0,01) \times 10^{4} \mathrm{KУO/мл,} \mathrm{у} \mathrm{порів-}$ нянні з результатами застосування пневмошолома без захисних бар'єрів - $(3,60 \pm 0,70) \times 10^{4}$ КУО/мл.

Таблиця 1. Оцінка ефективності фільтрувальних компонентів пневмошолома при тривалості досліду 6 год

\begin{tabular}{|l|c|c|c|}
\hline \multirow{2}{*}{ Матеріал } & \multicolumn{3}{|c|}{ Комплектація пневмошолома } \\
\cline { 2 - 4 } & $\begin{array}{c}\text { повна комплекта- } \\
\text { ція, КУО/мл }\end{array}$ & $\begin{array}{c}\text { використання марлевих } \\
\text { масок замість фільтрів } \\
\text { № 1 та № 2, КУО/мл }\end{array}$ & $\begin{array}{c}\text { без внутрішнього та зовніш- } \\
\text { нього фільтра, } \\
\text { КУО/мл }\end{array}$ \\
\hline Контроль & 0 & 0 & 0 \\
\hline Середовище & 0 & $0,08 \pm 0,01 \times 10^{4 *}$ & $3,60 \pm 0,70 \times 10^{4 *}$ \\
\hline Внутрішня сторона фільтра № 1 & 0 & - & - \\
\hline Зовнішня сторона фільтра № 1 & 0 & - & $1,44 \pm 0,37 \times 10^{4 *}$ \\
\hline Лопасті вентилятора & 0 & $0,38 \pm 0,05 \times 10^{4 *}$ & - \\
\hline Внутрішня сторона фільтра № 2 & 0 & - & - \\
\hline Зовнішня сторона фільтра № 2 & $3,40 \pm 0,20 \times 10^{4 *}$ & - & \\
\hline
\end{tabular}

Примітка: * - достовірна відмінність із контролем досліду $(p<0,001)$.

Для оцінки особливостей потенційного бактеріального обсіменіння внутрішньої поверхні пневмошолома була застосована шефілдська голова-манекен. Ефективність протибактеріального захисту при повній комплектації не дозволила провести це вимірювання, оскільки статистично не відрізнялася від контролю (змивів із обличчя, шиї голови-манекена та внутрішньої поверхні скла після простою приладу у вимкнутому стані впродовж зазначеного терміну). Чисельність бактерій при використанні марлевих масок в якості фільтруючих компонентів була відносно незначною та достовірно не відрізнялася у різних частинах голови-манекена (табл. 2).

Таблиця 2. Оцінка бактерійного обсіменіння шефілдської голови-манекена

\begin{tabular}{|l|c|c|c|}
\hline \multirow{2}{*}{ Матеріал } & \multicolumn{3}{|c|}{ Комплектація пневмошолома } \\
\cline { 2 - 4 } & $\begin{array}{c}\text { повна } \\
\text { комплектація, } \\
\text { КУО/мл }\end{array}$ & $\begin{array}{c}\text { використання марлевих } \\
\text { масок замість фільтрів } \\
\text { № 1 та № 2, КУО/мл }\end{array}$ & $\begin{array}{c}\text { відсутність фільтруючих } \\
\text { компонентів, КУО/мл }\end{array}$ \\
\hline Контроль & 0 & 0 & 0 \\
\hline Змиви з нижньої частини обличчя & 0 & $0,02 \pm 0,01 \times 10^{3 *}$ & $2,50 \pm 0,10 \times 10^{3 *}$ \\
\hline Змиви з верхньої частини обличчя & 0 & $0,06 \pm 0,02 \times 10^{3 *}$ & $4,80 \pm 0,20 \times 10^{3 *}$ \\
\hline Змиви з шиї & 0 & $0,01 \pm 0,01 \times 10^{3 *}$ & $1,00 \pm 0,30 \times 10^{3 *}$ \\
\hline $\begin{array}{l}\text { Змиви з внутрішньої поверхні за- } \\
\text { хисного скла }\end{array}$ & 0 & $0,03 \pm 0,02 \times 10^{3 *}$ & $3,40 \pm 0,20 \times 10^{3 *}$ \\
\hline
\end{tabular}

Примітка: * - достовірна відмінність із контролем досліду $(p<0,001)$.

При відсутності фільтрувальних компонентів найбільше число КУО/мл виявлено у змивах із внутрішньої поверхні захисного скла - $(3,40 \pm$ $0,20) \times 10^{3}$, та верхньої частини обличчя - $(4,80 \pm$ $0,20) \times 10^{3}$. Найменша кількість бактерій була знайдена у змивах із ділянок шиї, яку вкривала нижня частина пневмошолома, - $(1,00 \pm 0,30) \times 10^{3}$ КУО/мл (рис. 1).
Отриманий рівень протибактеріального захисту при застосуванні марлевих масок відповідає існуючим вимогам стосовно загальнодоступних засобів захисту органів дихання (більше 95,0 \%). Проте повна комплектація запропонованої концепт-моделі відзначилась вищим рівнем біологічної безпеки, що особливо важливо в умовах підвищеного ризику. 


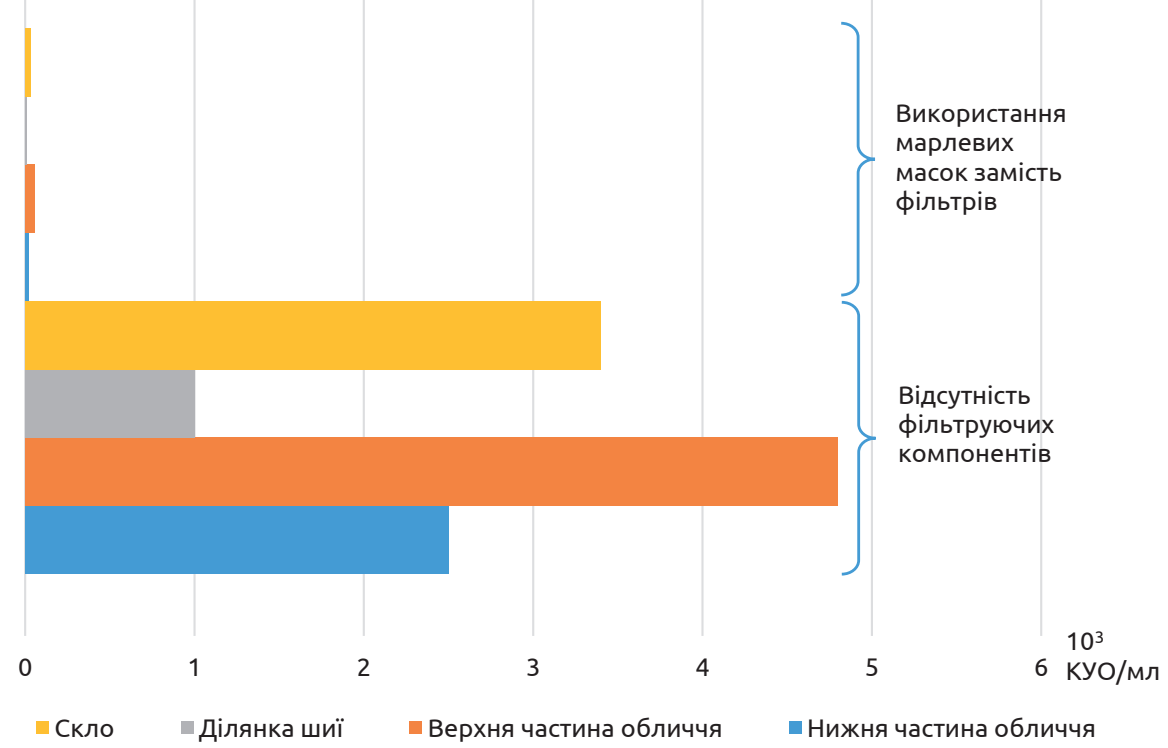

Рис. 1. Показники вірусного обсіменіння поверхонь внутрішнього простору концепт-моделі при відсутності основних фільтруючих елементів.

Запропонована концепт-модель не містить спеціальних отворів для виведення відпрацьованого повітря, адже воно виходить унаслідок дії позитивного тиску через нижній контур пневмошолома. Ця конструкторська особливість дозволяє підвищити ергономічність, знизити складність та вартість її виготовлення. Однак вищенаведене робить нижній контур потенційним місцем для проникнення інфекції. Відсутність росту Місгососсиs luteus з покритих поверхонь шиї шефілдської голови-манекена при повній комплектації концепт-моделі, найнижчі рівні бактерійного обсіменіння зазначеної ділянки при неповній комплектації свід- чать про достатній рівень позитивного тиску вихідного повітря для збереження протибактеріального захисту. Повна комплектація пристрою забезпечила надійний протибактеріальний захист впродовж 6-ти годин безперервної роботи.

Висновки. Підтвердження ефективності фільтраційної та ізолювальної здатності пропонованої системи стосовно її непроникності для тестової культури із відсутністю росту на живильних середовищах при безперервному функціонування протягом 6-ти годин. Достатній рівень позитивного тиску забезпечує непроникність нижнього контуру для мікроорганізмів.

\section{ЛІТЕРАТУРА}

1. Selection of effective filter respirators. Challenges and opportunities / S. Cheberiachko, O. Deryugin, V. Mirnenko, N. Borodina // Journal of Scientific Papers "Social Development and Security". - 2020.- Vol. 10(4). - 23-41. https://doi.org/10.33445/sds.2020.10.4.3

2. Face Masks and Respirators in the Fight against the COVID-19 Pandemic: A Review of Current Materials, Advances and Future Perspectives / K. O'Dowd, K. Nair, M. P. Forouzandeh [et al.] // Materials (Basel, Switzerland). - 2020. 13(15).-P. 3363. https://doi.org/10.3390/ma13153363

3. Viral Filtration Efficiency of Fabric Masks Compared with Surgical and N95 Masks / H. Whiley, T. P. Keerthirathne, M. A. Nisar [ et al.] // Pathogens (Basel, Switzerland). - 2020. - Vol. 9(9). - P. 762. https://doi.org/10.3390/ pathogens 9090762

4. Where do we stand to oversee the coronaviruses in aqueous and aerosol environment? Characteristics of transmission and possible curb strategies / B. Ji, Y. Zhao, A. Esteve-Núñez [et al.] // Chemical engineering journal
(Lausanne, Switzerland). - 2021. - Vol. 413. - P. 127522. https://doi.org/10.1016/j.cej.2020.127522

5. ДСТУ EN 149:2017 Засоби індивідуального захисту органів дихання. Фільтрувальні півмаски для захисту від аерозолів. Вимоги, випробування, маркування (EN 149:2001+A1:2009, IDT). Чинний від 2018-02-01. Київ, 2018. Держспоживстандарт України. URL: http://online. budstandart.com/ua/catalog/doc-page?id_doc=75012

6. Особливості раціонального використання засобів індивідуального захисту при роботі з пацієнтами 3 гострою респіраторною хворобою COVID-19 на амбулаторному етапі / Ю. О. Данилевич, Л. П. Мазур, С. О. Ястремська // Медсестринство. - 2020. - № 2. C. 5-8. DOI: 10.11603/2411-1597.2020.2.11228

7. Defining Aerosol Generating Procedures and Pathogen Transmission Risks in Healthcare Settings / J. Li, A. Leavey, W. Yang [et al.] // Open Forum Infectious Diseases. - 2017. - Vol. 4 (Suppl.1). - P. S34-S35. https://doi. org/10.1093/ofid/ofx162.085 
Огляди літератури, оригінальні дослідження, погляд на проблему, випадок з практики, короткі повідомлення REFERENCES

1. Cheberiachko, S., Deryugin O., Mirnenko, V., \& Borodina, N. (2020). Selection of effective filter respirators. Challenges and opportunities. Journal of Scientific Papers "Social Development and Security», 10 (4), 23-41. https:// doi.org/10.33445/sds.2020.10.4.3

2. O'Dowd, K., Nair, K.M., Forouzandeh, P., Mathew, S., Grant, J., Moran, R., Bartlett, J., Bird, J., \& Pillai, S.C. (2020). Face Masks and Respirators in the Fight against the COVID-19 Pandemic: A Review of Current Materials, Advances and Future Perspectives. Materials (Basel, Switzerland), 13 (15), 3363. https://doi.org/10.3390/ ma13153363

3. Whiley, H., Keerthirathne, T.P., Nisar, M.A., White, M., \& Ross, K.E. (2020). Viral Filtration Efficiency of Fabric Masks Compared with Surgical and N95 Masks. Pathogens (Basel, Switzerland), 9 (9), 762. https://doi.org/10.3390/ pathogens9090762

4. Ji, B., Zhao, Y., Esteve-Núñez, A., Liu, R., Yang, Y., Nzihou, A., Tai, Y., Wei, T., Shen, C., Yang, Y., Ren, B., Wang, X., \& Wang, Y. (2021). Where do we stand to oversee the coronaviruses in aqueous and aerosol environment? Characteristics of transmission and possible curb strategies. Chemical Engineering Journal (Lausanne, Switzerland), 413, 127522. https://doi.org/10.1016/j.cej.2020.127522

5. DSTU EN 149:2017 Zasoby indyvidualnoho zakhystu orhaniv dyhannia. Filtruvalni pivmaskydlia zahystu vidaeroziliv. Vymohy, vyprobuvannia, markuvannia (EN 149:2001 +A1:2009, IDT) Chynnyi vid 2018-02-01. Kyiv,2018. Derzhspozhyvstandart Ukrainy. [DSTU EN 149: 2017 Respiratory protective devices. Filtering southern for protection against aerosols. Requirements, tests, markings (EN 149: 2001 + A1: 2009, IDT). Valid from 02/01/2018. Kyiv, 2018. Derzhspozhyvstandart of Ukraine.] URL: http://online. budstandart.com/ua/catalog/doc-page?id_doc=75012

6. Danylevych, Yu.O., Mazur L.P., \& Yastremska, S.O. (2020). Osoblyvosti ratsionalnoho vykorystannia zasobiv indyvidualnoho zahystu pry roboti z patsientamy z hostroiu respiratornoiu khvoroboiu COVID-19 naambulatornomuetapi [Features of rational use of personal protective equipment when working with patients with acute respiratory disease COVID-19 at the outpatient stage]. Medsestrynstvo- Nursing, 2, 5-8. https://doi.org/10.11603/2411-1597.2020.2.11228

7. Li, J., Leavey, A., Yang, W., O'Neil, C., Wallace, M., Boon, A., Biswas, P., Burnham, C., \& Babcock, H.M. (2017). Defining Aerosol Generating Procedures and Pathogen Transmission Risks in Healthcare Settings. Open Forum Infectious Diseases, 4 (Suppl 1), S34-S35. https://doi.org/10.1093/ofid/ of $x 162.085$

\section{COMPARATIVE EFFICIENCY OF THE LAMINAR PNEUMATIC PROTECTION SYSTEM FOR COUNTERACTING THE PENETRATION OF BACTERIAL AGENTS}

\section{@I. M. Klishch, A. O. Kovalchuk, I. I. Medvid, A. V. Pavlyshyn, S. I. Klymnyuk I. Horbachevsky Ternopil National Medical University}

SUMMARY. The COVID-19 coronavirus pandemic has necessitated the development of new respiratory protective devices that combine reliability and ergonomics of use. The study performed an experimental evaluation of the bacterial impermeability of an innovative conceptual model of a pneumatic helmet with a laminar air supply system.

The aim - to conduct a comparative assessment of the filtering capacity of the proposed conceptual model of a pneumatic helmet with the determination of its permeability for bacterial culture of micrococci. Evaluate the features of a potential bacterial spreading inside the device.

Material and Methods. The developed conceptual model of a pneumatic helmet was tested to determine its resistance to bacterial agents (Micrococcus luteus) for six hours of continuous operation. The microorganisms were fed in the form of an aerosol to the external filter of the operating device, followed by titration and seeding. Assessment of bacterial amount was performed by counting colony-forming units. A Sheffield dummy head was used to study the features of potential bacterial spreading in the interior of the device. The study was repeat when replacing filters with gauze masks and removing them. As a control, the nutrient medium container was placed inside the off helmet for the specified period

Results. The use of a pneumatic helmet in a complete set counteracted the impregnation of bacterial aerosol, which manifested itself in the absence of growth on nutrient media. In the absence of filters, the highest levels of bacterial contamination were determined on the inner surface of the glass and the upper part of the front of the Sheffield manikin. When replacing the filters with gauze masks, $98.8 \%$ of microorganisms were saved compared to the results of using a pneumatic helmet without protective barriers.

Conclusions. Confirmation of filtration efficiency and insulating capacity of the proposed system in relation to its impermeability for testing the culture without growth on nutrient media. The protection of the lower contour of the pneumatic helmet against microorganisms has been confirmed.

KEY WORDS: laminar pneumatic protection system; pneumatic helmet; antibacterial protection; micrococci.

Отримано 12.09.2021 